\title{
Analiza pojęć „logika” i „logiczny” w encyklikach Jana Pawła II
}

\section{Analysis of the concepts of 'logic' and 'logical' in the encyclicals of Pope John Paul II}

\author{
Wtodzimierz Lapis \\ INSTYTUT JĘZYKOZNAWSTWA, UNIWERSYTET IM. ADAMA MICKIEWICZA, \\ AL. NEIPODLEGŁOŚCI 4, 61-874 POZNAŃ \\ lapisweamu.edu.pl
}

\begin{abstract}
In this paper I examine the perception of the concepts of 'logic' and 'logical' by John Paul II, The source material includes his 14 encyclicals (though both words occur only in eight of them a total of 38 times). As it turns out, the Pope sees logic as a science, a human system, or activity (human or divine). He uses the term 'logical' to refer to the 'logical conclusion' and 'logical thinking'.
\end{abstract}

\section{Wstęp}

W zbliżającym się 2011 r. spodziewana jest beatyfikacja Karola Wojtyły Papieża Jana Pawła II. W związku z tym coraz większe zainteresowanie wzbudzają Jego Osoba i dokonania, w tym wystąpienia i publikacje. Na szczególną uwagę zasługują podstawowe dokumenty papieskie, jakimi są encykliki. Jan Paweł II w okresie od marca 1979 do kwietnia 2003 r. napisał ich łącznie 14. Zauważmy przy tym, że choć w przypadku encyklik oficjalny charakter miała zawsze łacińska wersja ich tekstu, która służyła do przekładów na inne języki nowożytne, to jednak Papież wszystkie je pisał po polsku. Polski ich tekst nie jest więc zniekształcony w wyniku tłumaczenia, a zatem wiernie oddaje myśl Jana Pawła II, co jest niezmiernie istotne przy jego analizie.

W pracy tej przeanalizujemy występowanie słów „logika” i „logiczny” w encyklikach papieskich oraz ich rozumienie przez Jana Pawła II. Ze względu na należną Mu cześć w artykule będziemy używać wielkich liter. Każda z pisanych przez Papieża encyklik składa się z kilkudziesięciu (nieraz ponad stu) numerowanych paragrafów. Cytując ich fragmenty zawierające analizowane słowo, będziemy podawać całe owe numerowane paragrafy lub jedynie ich fragmenty - wtedy jednak pominięte fragmenty paragrafów zostaną zastąpione wykropkowaniem. Aby wyraźnie odróżnić analizowane 
teksty od ich analizy, będziemy je podawać z wcięciem z prawej strony. Ponadto, by w przytaczanym tekście łatwiej było zlokalizować badane słowo, każdorazowo zostało ono wyróżnione szarym tłem.

Aby zyskać właściwy punkt odniesienia, poniżej cytujemy znaczenie słów „logika” i „logiczny” podane w trzytomowym słowniku języka polskiego (występujące w nim rodzime im słowa „logicznie” / przysłówek od „logiczny”/ i „logiczność” /rzeczownik od „logiczny”/, w badanych encyklikach nie pojawiają się).

\section{Logika:}

1) dyscyplina należaca do nauk filozoficznych, normatywna nauka o formach poprawnego myślenia, obejmujaca obecnie logike formalna, semantykę logiczna, teorię wnioskowania indukcyjnego, metodologię nauk oraz pewne zagadnienia techniki pracy umysłowej i erystyki,

2) poprawne myślenie, właściwe rozumowania, zdrowy rozsądek,

3) logiczność, sensowność, sens czegoś; konsekwencja, prawidłowość.

\section{Logiczny:}

1) odnoszacy się do logiki - dyscypliny filozoficznej,

2) poprawnie myślacy; zgodny z logika, sensowny rozsądny, konsekwentny.

\begin{tabular}{|c|c|c|c|c|c|}
\hline \multirow{2}{*}{ Lp. } & \multirow{2}{*}{ Tytuł encykliki ${ }^{1}$} & \multirow{2}{*}{$\begin{array}{l}\text { Data } \\
\text { napisania }\end{array}$} & \multicolumn{3}{|c|}{ Liczba wystąpień } \\
\hline & & & „logika” & $\begin{array}{l}\text { "logicz- } \\
\text { ny” }\end{array}$ & $\begin{array}{l}\mathrm{Su}- \\
\mathrm{ma}\end{array}$ \\
\hline 1 & $\begin{array}{l}\text { Redemptor hominis (Odkupiciel człowie- } \\
\mathrm{ka} \text { ) }\end{array}$ & 4 marca 1979 & & & \\
\hline 2 & $\begin{array}{l}\text { Dives in misericordia (Bogaty w Miło- } \\
\text { sierdziu); O Bożym Miłosierdziu }\end{array}$ & $\begin{array}{l}\text { 30 listopada } \\
1980\end{array}$ & & & \\
\hline 3 & $\begin{array}{l}\text { Laborem exercens ( } Z \text { pracy); O pracy } \\
\text { ludzkiej }\end{array}$ & $\begin{array}{l}14 \text { września } \\
1981\end{array}$ & & & \\
\hline 4 & $\begin{array}{l}\text { Slavorum apostoli (Apostołowie Sto- } \\
\text { wian); Na } 11 \text { oo rocznice dzieła ewangeli- } \\
\text { zacji Sw. Cyryla i Metodego }\end{array}$ & $\begin{array}{l}2 \text { czerwca } \\
1985\end{array}$ & & & \\
\hline 5 & $\begin{array}{l}\text { Dominum et vivificantem (Pana i Ożywi- } \\
\text { ciela); O Duchu Świętym w życiu Kościo- } \\
\text { ta i świata }\end{array}$ & 18 maja 1986 & 2 & & 2 \\
\hline 6 & $\begin{array}{l}\text { Redemptoris Mater (Matka Odkupicie- } \\
\text { la); Błogostawiona Maryja Dziewica } w \\
\text { życiu pielgrzymującego Kościoła }\end{array}$ & $\begin{array}{l}25 \text { marca } \\
1987\end{array}$ & & & \\
\hline
\end{tabular}

${ }^{1}$ Kolejno: tytuł encykliki - który zgodnie z tradycją kościelną tworzą pierwsze słowa jej oficjalnego tekstu, jego tłumaczenie na język polski - podane w nawiasie na podstawie polskiego tekstu, podtytuł po średniku (zawierają go wszystkie encykliki oprócz pierwszej). 
Włodzimierz Lapis: Analiza pojęć „logika” $i$ „logiczny” $w$ encyklikach Jana Pawta II

\begin{tabular}{|c|c|c|c|c|c|}
\hline 7 & $\begin{array}{l}\text { Sollicitudo rei socialis (Spoteczna tro- } \\
\text { ska); Spoteczna troska }\end{array}$ & $\begin{array}{l}30 \text { grudnia } \\
1987\end{array}$ & 1 & 2 & 3 \\
\hline 8 & $\begin{array}{l}\text { Redemptoris missio (Misja Odkupiciela); } \\
\text { O statej aktualności postania misyjnego }\end{array}$ & $\begin{array}{l}7 \text { grudnia } \\
1990\end{array}$ & & & \\
\hline 9 & $\begin{array}{l}\text { Centesimus annus (Stulecie); W stulecie } \\
\text { encykliki Leona XIII „Rerum Novarum” }\end{array}$ & 1 maja 1991 & 8 & & 8 \\
\hline 10 & $\begin{array}{l}\text { Veritatis splendor (Blask prawdy); Pod- } \\
\text { stawowe problemy nauczania moralne- } \\
\text { go Kościoła }\end{array}$ & $\begin{array}{l}6 \text { sierpnia } \\
1993\end{array}$ & 1 & 1 & 2 \\
\hline 11 & $\begin{array}{l}\text { Evangelium vitae (Ewangelia życia); } O \\
\text { wartości i nienaruszalności życia ludz- } \\
\text { kiego }\end{array}$ & $\begin{array}{l}25 \text { marca } \\
1995\end{array}$ & 6 & 2 & 8 \\
\hline 12 & $\begin{array}{l}\text { Ut unum sint (w tekście polskim tytuł } \\
\text { zachowany w wersji lacińskiej; sens: Aby } \\
\text { byli jedno); O dziatalności ekumenicznej }\end{array}$ & 25 maja 1995 & 1 & & 1 \\
\hline 13 & $\begin{array}{l}\text { Fides et ratio (Wiara i rozum); O rela- } \\
\text { cjach między wiarq a rozumem }\end{array}$ & $\begin{array}{l}14 \text { września } \\
1998\end{array}$ & 8 & 5 & 13 \\
\hline 14 & $\begin{array}{l}\text { Ecclesia de Eucharistia (Kościół dzięki } \\
\text { Eucharystii); Eucharystia w życiu Ko- } \\
\text { ścioła }\end{array}$ & $\begin{array}{l}17 \text { kwietnia } \\
2003\end{array}$ & 1 & & 1 \\
\hline & & RAZEM & 28 & 10 & 38 \\
\hline
\end{tabular}

Tabela 1. Encykliki Jana Pawła II i wystapienia w nich badanych stów

\section{Encyklika Dominem et Vivificantem}

Pojęcia „logika” w encyklikach Papież po raz pierwszy użył w 11. paragrafie swej piątej encykliki Dominem et Vivificantem (poświęconej Duchowi Świętemu):

11. Przemówienie pożegnalne Chrystusa w czasie wieczerzy paschalnej pozostaje w szczególnym związku z tym „daniem” i „oddaniem się" Ducha Świętego. Oto odsłania się w zapisie Janowej Ewangelii jakby najgłębsza „logika” zbawczych tajemnic odwiecznych zamierzeń Boga, który jest niewysłowioną Jednością komunii Ojca, Syna i Ducha Świętego. Jest to „logika” Boża, która od tajemnicy Trójcy Świętej prowadzi do tajemnicy Odkupienia świata w Jezusie Chrystusie. Odkupienie spetnione przez Syna w wymiarach ziemskiej historii człowieka - spełnione w Jego „odejściu” przez Krzyż i Zmartwychwstanie - zostaje równocześnie w całej swojej zbawczej mocy przekazane Duchowi Świętemu: „z mojego weźmie” ( $J$ 16, 14). Słowa, które wedle Janowego zapisu wskazują, że zgodnie z zamysłem Bożym „odejście” Chrystusa jest nieodzownym warunkiem „posłania” i przyjścia Ducha Świętego, wskazują zarazem na nowy początek zbawczego udzielania się Boga w Duchu Świętym.

W każdym z tych dwóch przypadków słowo „logika” występuje w cudzysłowie, co wskazuje, że Papież czuje, iż dopiero adaptuje je do znaczenia, w którym go używa (jakby każdorazowo przed jego użyciem dopowiadał: 
„Swego rodzaju”). W pierwszym użyciu „logika” znaczy „zamysł Boży” (na co wskazuje pierwszy podkreślony przeze mnie fragment tekstu), a więc oznacza coś, co ma nastąpić. Stosując je za drugim razem, Papież precyzuje, że jest to „logika Boża”, która „prowadzi” (od tajemnicy Trójcy Świętej do tajemnicy Odkupienia świata w Jezusie Chrystusie), w związku z czym oznacza sposób zbawczego udzielania się Boga (kolejny podkreślony fragment). Tak więc w każdym z tych dwóch przypadków pojęcie „logika” ma charakter dynamiczny (potencjalny lub aktualny) oraz oznacza przemyślaną, racjonalną i nakierowaną na określony cel aktywność (tu: Bożą).

\section{Encyklika Solicitudo rei socialis}

Encyklika, w której kolejny raz Papież używa pojęcie „logika”, nosi tytuł Solicitudo rei socialis (jest to siódma encyklika Papieża, poświęcona trosce społecznej). Została ukończona w 1987 r., a więc u schyłku rozdziału Północy na dwa bloki: Wschód i Zachód.

Pojęcie „logika” pojawia się w niej $1 \mathrm{raz}$ - w paragrafie 23. Papież pisze w niej:

23. (...) Przeciwstawność ideologiczna, która sprzyja systemom i antagonistycznym ośrodkom władzy, przy użyciu własnych form propagandy i wpajania przekonań, doprowadziła nieuchronnie do rosnącej przeciwstawności militarnej, dając początek dwóm blokom uzbrojonych potęg, nieufnych wobec siebie i lękających się przewagi drugiego. Ze swej strony stosunki międzynarodowe nie mogły nie odczuwać skutków tej „logiki bloków” i odpowiadających im „sfer wpływów”. Napięcie między dwoma blokami, powstałe przy końcu drugiej wojny światowej, panowało w czasie całego następnego czterdziestolecia, przybierając bądź charakter „zimnej wojny” bądź „wojen per procura” drogą wykorzystywania konfliktów lokalnych lub też przez trzymanie ludzi w niepewności i niepokoju groźbą wojny otwartej i totalnej. (...)

Cudzysłów obejmuje tu oprócz słowa „logika” również sąsiadujące z nim słowo „bloki”, co znaczy, że tworzą one związek wyrazowy. Tym razem jednak ujęcie w cudzysłów sugeruje, że jest to „logika chybiona” - taka, która jest nam niepotrzebna i z którą Papież się nie zgadza.

Poza tym w encyklice tej występują dwa fragmenty ze słowem „logiczny”:

24. (...) Jeśli do tego wszystkiego doda się powszechnie znane straszliwe niebezpieczeństwo broni atomowych nagromadzonych w niewiarygodnych ilościach, nasuwa się następujący logiczny wniosek: tak widziany świat współczesny, łącznie ze światem ekonomii, zamiast troszczyć się o prawdziwy rozwój, wiodący wszystkich ku życiu „bardziej ludzkiemu” - jak tego pragnęła Encyklika Populorum progressio - zdaje się prowadzić nas szybko ku śmierci. 
30. (...) Płynie stąd logiczny wniosek, przynajmniej dla ludzi wierzących w Słowo Boże, że tak zwany współczesny rozwój należy widzieć jako etap historii zapoczątkowanej w dziele Stworzenia i ciągle zagrożonej z powodu niewierności wobec woli Stwórcy, zwłaszcza pokusą bałwochwalstwa; rozwój jednak zasadniczo jest zgodny z pierwotnymi założeniami. Kto by chciał odstąpić od trudnego, ale wzniostego zadania polepszania losu całego człowieka i wszystkich ludzi pod pretekstem ciężaru walki i stałego wysiłku przezwyciężania przeszkód czy też z powodu porażek i powrotu do punktu wyjścia, sprzeciwiałby się woli Boga Stwórcy. (...)

W obydwu tych fragmentach Papież używa określenia „logiczny wniosek”, który się „nasuwa” lub „płynie” z czegoś (co Papież najpierw przytacza), a nadto w drugim przypadku ciągnie argumentację, rozważając „co by bowiem było w przeciwnym przypadku", co jeszcze dobitniej wskazuje, że ów „logiczny wniosek” jest elementem argumentacji. Przy tym obydwa te „logiczne wnioski” odnoszą się jedynie do przekonań czy rozumienia (a więc do „świata myśli”).

\section{Encyklika Centesimus annus}

Kolejną omawianą przez nas encykliką jest encyklika społeczna z $1991 \mathrm{r}$. Centesimus annus (Stulecie), która z jednej strony (zgodnie ze swym podtytułem) nawiązuje do encykliki Leona XIII Rerum Novarum, a z drugiej do przemian ustrojowych w Europie Wschodniej dokonanych w $1989 \mathrm{r}$.

Pojęcie „logika” pada w niej (w porównaniu z poprzedniki encyklikami aż) 8 razy. Wymienimy i omówimy te wystąpienia w 4 częściach.

I CZĘŚĆ (1 fragment z 4 wystąpieniami słowa „logika”)

18. (...) Logika bloków i imperiów, piętnowana w Dokumentach Kościoła, a ostatnio w encyklice Sollicitudo rei socialis, sprawia, że spory i konflikty, pojawiające się w krajach Trzeciego Świata, są systematycznie podsycane i wykorzystywane dla stwarzania trudności przeciwnikowi. (...) Nad całym wreszcie światem zawisła groźba wojny atomowej, która może doprowadzić do zagłady ludzkości. Nauka, użyta do celów militarnych, oddaje w ręce nienawiści, podsycanej przez ideologie, narzędzie rozstrzygające. Ale wojna może prowadzić nie do zwycięstwa jednych i przegranej drugich, lecz do samobójstwa ludzkości. Należy więc odrzucić wiodącą do niej logikę oraz samą koncepcję, według której walka zmierzająca do zniszczenia przeciwnika, sprzeczność interesów i wojna to czynniki rozwoju i postępu historii. Świadome odrzucenie tej koncepcji niezawodnie prowadzi do załamania się zarówno logiki „wojny totalnej”, jak i logiki „walki klas". 
Opisana tu „logika bloków i imperiów” jest „logiką walki klas” - czy wręcz „logiką wojny totalitarnej”. Tego typu logikę - jako chybioną - należy oczywiście odrzucić.

II CZĘŚĆ (2 fragmenty - w każdym słowo „logika” występuje 1 raz)

34. Wydaje się, że zarówno wewnątrz poszczególnych narodów, jak i w relacjach międzynarodowych wolny rynek jest najbardziej skutecznym narzędziem wykorzystania zasobów i zaspokajania potrzeb. Dotyczy to jednak tylko tych potrzeb, za których zaspokojenie można zapłacić, to jest które dysponują siłą nabywczą, i tych zasobów, które „nadają się do sprzedania”, czyli mogą uzyskać odpowiednią cenę. Istnieją jednak liczne ludzkie potrzeby, które nie mają dostępu do rynku. W imię sprawiedliwości i prawdy nie wolno dopuścić do tego, aby podstawowe ludzkie potrzeby pozostały niezaspokojone i do wyniszczenia z tego powodu ludzkich istnień. Konieczne jest też udzielenie ludziom potrzebującym pomocy w zdobywaniu wiedzy, we włączaniu się w system wzajemnych powiązań, w rozwinięciu odpowiednich nawyków, które pozwolą im lepiej wykorzystać własne zdolności i zasoby. Ważniejsze niż logika wymiany równowartości i niż różne formy sprawiedliwości, które się z tym wiążą, jest to, co należy się człowiekowi, ponieważ jest człowiekiem, ze względu na jego wzniosłą godność. To, co należy się człowiekowi, musi gwarantować możliwość przeżycia i wniesienia czynnego wkładu w dobro wspólne ludzkości.

40. Do obowiązków Państwa należy troska o obronę i zabezpieczenie takich dóbr zbiorowych jak środowisko naturalne i środowisko ludzkie, których ochrony nie da się zapewnić przy pomocy zwykłych mechanizmów rynkowych. Jak w czasach dawnego kapitalizmu na państwie spoczywał obowiązek obrony podstawowych praw pracy, tak teraz wobec nowego kapitalizmu na Państwie i całym społeczeństwie spoczywa obowiązek obrony dóbr zbiorowych, stanowiących między innymi ramy wyznaczające jedyną przestrzeń, w której człowiek może w uprawniony sposób realizować własne, indywidualne cele.

Stanowi to nowe ograniczenie rynku: istnieją potrzeby zbiorowe i jakościowe, których nie da się zaspokoić za pośrednictwem jego mechanizmów. Istnieją ważne wymogi ludzkie, które wymykają się jego logice. Istnieją dobra, których ze względu na ich naturę nie można i nie należy sprzedawać i kupować. Niewątpliwie mechanizmy rynkowe niosą pewne korzyści: m.in. służą lepszemu wykorzystaniu zasobów, ułatwiają wymianę produktów, a zwłaszcza w centrum zainteresowania umieszczają wolę i upodobania osoby ludzkiej, umożliwiając jej w chwili zawierania kontraktu spotykanie z wolą i upodobaniami innej osoby. Wiąże się z nimi jednak niebezpieczeństwo przyjęcia wo- 
bec rynku postawy „bałwochwalczej”, nie biorącej pod uwagę istnienia dóbr, które ze swej natury nie mogą być zwykłymi towarami.

W obydwu tych fragmentach Papież mówi odpowiednio o „logice wymiany równowartości” i o „logice rynku”, które, choć dobre, to jednak nie w pełni zaspokajają potrzeby ludzkie, gdyż niektóre z nich nie są w stanie być przez nie zaspokojone.

III CZĘŚĆ (1 fragment, w którym słowo „logika” występuje 1 raz)

48. (...) Byliśmy w ostatnich latach świadkami znacznego poszerzenia zakresu tego rodzaju interwencji, co doprowadziło do powstania w pewnym sensie nowego typu Państwa - „Państwa dobrobytu”. (...) Interweniując bezpośrednio i pozbawiając społeczeństwo odpowiedzialności, Państwo opiekuńcze powoduje utratę ludzkich energii i przesadny wzrost publicznych struktur, w których - przy ogromnych kosztach - raczej dominuje logika biurokratyczna, aniżeli troska o to, by służyć korzystającym z nich ludziom. Istotnie, wydaje się, że lepiej zna i może zaspokoić potrzeby ten, kto styka się z nimi z bliska i kto czuje się bliźnim człowieka potrzebującego. Przy tym często pewnego rodzaju potrzeby wymagają odpowiedzi wykraczającej poza porządek tylko materialny, takiej mianowicie, która potrafi wyjść naprzeciw głębszym potrzebom ludzkim. Należy tu pomyśleć o sytuacji uchodźców, emigrantów, osób starych lub chorych i o tylu innych osobach wymagających opieki, jak choćby narkomani; ludziom tym skutecznie może pomóc tylko ten, kto oprócz koniecznego leczenia zaofiaruje im szczere braterskie oparcie.

Ukazana w tym fragmencie „logika biurokratyczna” występuje w państwie nadmiernie opiekuńczym, jest złym dla ludzi „porządkiem”.

IV CZĘŚŚ (z 1 wystąpieniem słowa „logika”):

57. (...) Dziś bardziej niż kiedykolwiek Kościół jest świadom, że jego orędzie społeczne zyska większą wiarygodność dzięki świadectwu działania, niż dzięki swej wewnętrznej spójności i logice. (...)

W tym przypadku Papież stwierdza, że:

1) „orędzie społeczne Kościoła” ma swą wewnętrzna spójność i logikę (choć wydaje się, że te dwa pojęcie $\mathrm{w}$ tym miejscu mają to samo znaczenie) - logika jest więc jego cechą konstytutywną, czymś koniecznym, jego umocowaniem,

2) z drugiej zaś strony - że logika stanowi „suchą teorię”, a tu trzeba konkretnego działania („wewnętrzna logika” nim nie jest, podczas 
gdy w pierwszej z omawianych tu encyklik logika miała właśnie charakter dynamiczny).

Logika jest więc warunkiem koniecznym, ale już nie wystarczającym „społecznego orędzia Kościoła”.

Podsumujmy więc, że w encyklice tej Papież logikę - w zależności od tego, do czego się odnosi - określa jako: złą, choć dobrą, to jednak nie w pełni zaspokajającą potrzeby ludzkie, konieczną, ale nie wystarczającą.

\section{Encyklika Veritatis splendor}

Encyklika ta (z 1993 r.) poświęcona jest podstawowym problemom nauczania moralnego Kościoła.

Znajdziemy w niej jedynie 2 wystąpienia interesujących nas słów.

68. Trzeba tu jeszcze dodać bardzo ważną uwagę pastoralną. Zgodnie z logiką przytoczonych wyżej poglądów człowiek mógłby - mocą opcji fundamentalnej - dochowywać wierności Bogu niezależnie od tego, czy niektóre jego akty wyboru i czyny byłyby zgodne ze szczegółowymi normami i przepisami moralnymi. Na skutek pierwotnej opcji na rzecz miłości, człowiek miałby pozostawać moralnie dobrym, trwać w łasce Bożej i osiągnąc własne zbawienie, nawet gdyby poprzez niektóre swoje czyny sprzeciwiał się świadomie i w rzeczy ważnej przykazaniom Bożym przedstawionym na nowo przez Kościół. (...)

We fragmencie tym Jan Paweł II wskazuje na związek „logiki poglądów” $\mathrm{z}$ działaniem człowieka.

81. Nauczając o istnieniu czynów wewnętrznie złych, Kościół opiera się na doktrynie Pisma Świętego. Apostoł Paweł stwierdza stanowczo: „Nie łudźcie się! Ani rozpustnicy, ani bałwochwalcy, ani cudzołożnicy, ani rozwięźli, ani mężczyźni współżyjący z sobą, ani złodzieje, ani chciwi, ani oszczercy, ani zdziercy nie odziedziczą królestwa Bożego" (1 Kor 6, 9-10).

Jeśli czyny są wewnętrznie złe, dobra intencja lub szczególne okoliczności mogą łagodzić ich zło, ale nie mogą go usunąć: są to czyny „nieodwracalnie" złe, same z siebie i same w sobie niezdatne do tego, by je przyporządkować Bogu i dobru osoby: „Jeśli czyny są same z siebie grzechami (vum iam opera ipsa peccata sunt) - pisze św. Augustyn - jak na przykład kradzież, cudzołóstwo, bluźnierstwo lab tym podobne, to któż ośmieliłby się twierdzić, że gdy dokonane zostają dla dobrych powodów (causis bonis), nie są już grzechami lub - co jeszcze bardziej nielogiczne - są grzechami usprawiedliwionymi?"

Tak więc okoliczności lub intencje nie zdołają nigdy przekształcić czynu ze swej istoty niegodziwego ze względu na przedmiot w czyn 
Wtodzimierz Lapis: Analiza pojęć „logika” i „logiczny” w encyklikach Jana Pawta II

„subiektywnie” godziwy lub taki, którego wybór można usprawiedliwić.

W tym przypadku jest to jedyne miejsce, gdzie

- $\mathrm{z}$ jednej strony - występuje rozważane słowo poprzedzone cząstką „nie"

- z drugiej zaś strony - występuje ono w cytacie z innego autora (tu: św. Augustyna).

Papież, przytaczając je, daje wyraz swemu przekonaniu, że się z nim zgadza. Tym samym uznaje, że czyny (grzechy są czynami) mogą być nielogiczne. W tym przypadku niepodobna bowiem, aby złe postępowanie było dobre (gdyby tak było - byłoby to nielogiczne). Zwróćmy przy tym uwagę na fakt, że występuje tu nie tylko kategoria „nielogiczne” (że grzech przestanie być grzechem), ale nawet „bardziej nielogiczne” (że istnieją grzechy usprawiedliwione).

\section{Encyklika Evangelium vitae}

Równie bogata w badane słowa jak Contesimus annus, bo również zawierająca 8 ich wystąpień, jest 11. encyklika Jana Pawła II - Evangelium vitae (Ewangelia życia); O wartości i nienaruszalności życia ludzkiego z 25 marca $1995 \mathrm{r}$.

Obok zagadnień społecznych, kwestia obrony życia była bowiem równie ważnym aspektem nauczania Jana Pawła II, na którym szczególnie Mu zależało, w wyniku czego próbował maksymalnie w pełni i dobrze „logicznie" je uzasadnić.

Omawianie tej encykliki również poprowadzimy w 4. częściach.

I CZĘ̧ŚĆ, w której omówimy 2 wystąpienia słowa „logika”

8. (...) U korzeni wszelkiej przemocy skierowanej przeciw bliźniemu leży ustępstwo na rzecz „logiki” Ztego, to znaczy tego, który „od początku był zabójcą" (por. J 8, 44), jak przypomina nam apostoł Jan: „Taka bowiem jest wola Boża, którą objawiono nam od początku, abyśmy się wzajemnie miłowali. Nie tak, jak Kain, który pochodził od Złego i zabił swego brata" (1 J 3, 11-12). Tak więc zabójstwo brata od zarania historii jest smutnym świadectwem tego, z jak przerażającą szybkością szerzy się zło: do buntu człowieka przeciw Bogu w rajskim ogrodzie, dołącza się śmiertelna walka człowieka przeciw człowiekowi. (...)

W tym przypadku słowo „logika” jest ujęta w cudzysłowie, by dać wyraz przekonaniu, że „Zle” jest nielogiczne („Złe” - to Szatan, jego działanie i konsekwencje jego działania; o jego nielogiczności świadczą 3 paralelne fragmenty z Ewangelii: Mt 12, 22-30, Mk 3, 22-30 i Łk 11, 14-23). 
14. (...) Badania prenatalne, które nie wzbudzają obiekcji moralnych, o ile są podejmowane w celu wskazania ewentualnych terapii, których podjęcia wymaga zdrowie dziecka nie narodzonego, zbyt często dostarczają okazji do zaproponowania i wykonywania przerwania ciąży. Jest to wówczas aborcja eugeniczna, akceptowana przez opinię publiczną o specyficznej mentalności, co do której ustala się błędny pogląd, że jest ona wyrazem wymogów „terapeutycznych”: mentalność ta przyjmuje życie tylko pod pewnymi warunkami, odrzucając ułomność, kalectwo i chorobę.

Ta sama logika doprowadza do sytuacji, w których odmawia się podstawowego leczenia i opieki, a nawet pożywienia dzieciom urodzonym z poważnymi ułomnościami lub chorobami. Obraz współczesnego świata staje się jeszcze bardziej niepokojący w związku ze zgłaszanymi tu i ówdzie propozycjami, by uznać za prawnie dopuszczalne - na tej samej zasadzie co przerywanie ciąży - nawet dzieciobójstwo. Oznaczałoby to powrót do epoki barbarzyństwa, z której - jak się wydawało - wyszliśmy już raz na zawsze. (...)

W tym przypadku porównuje się jedną logikę z drugą, przy czym:

1) każda z nich jest chybiona,

2) i oznacza „błędny pogląd”, który może mieć złe konsekwencje.

W obydwu omówionych w tej części przypadkach omówiona jest „logika złego”, prowadząca - kierującą się nią osobę - „na manowce”.

II CZE_ŚĆ, w której omówimy 2 wystąpienia słowa „logiczny”.

61. Teksty Pisma Świętego, które w ogóle nie mówią o dobrowolnym przerwaniu ciąży, a więc nie zawierają bezpośredniego i określonego potępienia tego czynu, wyrażają wielki szacunek dla ludzkiej istoty w łonie matczynym, co każe nam wyciągnąc logiczny wniosek, że także ona jest objęta Bożym przykazaniem: „nie zabijaj”. (...)

Tutaj po raz kolejny (trzeci) pojawia się określenie „logiczny wniosek” (dotychczas - 2 razy - wystąpił w encyklice Solicitudo rei socialis), który można „wyciągnąć”. Tym razem jednak, zapewne ze względu na ważność poruszanej sprawy (jaką jest życie ludzie), Papież stwierdza, że fakt ten nie tyle pozwala, co wręcz „każe” „wyciągnąć logiczny wniosek”, a nawet używa słowa „nam” („każe nam wyciągnąć logiczny wniosek”), które wskazuje na nas wszystkich, abyśmy poczuli, że jest to nasza wspólna sprawa (bynajmniej nie jest to liczba mnoga 1. osoby, jaką zwykli używać papieże w odniesieniu do własnej osoby, gdyż Jan Paweł II nigdy nie używa jej w encyklikach). 
64. (...) Śmierć jest uważana za „bezsensowną”, kiedy niespodziewanie kładzie kres życiu otwartemu jeszcze na przyszłość, która może przynieść wiele interesujących doświadczeń; staje się natomiast „upragnionym wyzwoleniem”, gdy ludzka egzystencja zostaje uznana za pozbawioną dalszego sensu, ponieważ jest pogrążona w bólu i nieuchronnie wystawiona na coraz dotkliwsze cierpienie. (...)

W takim kontekście coraz silniejsza staje się pokusa eutanazji, czyli zawtadnięcia śmiercia poprzez spowodowanie jej przed czasem i „łagodne” zakończenie życia własnego lub cudzego. W rzeczywistości to, co mogłoby się wydawać logiczne i humanitarne, przy głębszej analizie okazuje się absurdalne i nieludzkie. Stajemy tu w obliczu jednego z najbardziej niepokojących objawów „kultury śmierci”, szerzącej się zwłaszcza w społeczeństwach dobrobytu, charakteryzujących się mentalnością nastawioną na wydajność, według której obecność coraz liczniejszych ludzi starych i niesprawnych wydaje się zbyt kosztowna i uciążliwa. Ludzie ci bardzo często są izolowani przez rodziny i społeczeństwo, kierujące się prawie wyłącznie kryteriami wydajności produkcyjnej, wedle których życie nieodwracalnie upośledzone nie ma już żadnej wartości.

To, czy coś jest logiczne, czy też nie, wymaga „głębszej analizy”. Niedogłębne, ludzkie spojrzenie na sprawę staje w sprzeczności z istotą ludzkości (tylko wydaje się humanitarne, w istocie okazuje się nieludzkie). Stosowanie przyziemnej miary staje w sprzeczności z wartościami wyższymi.

III CZĘŚĆ, w której omówimy 2 wystąpienia słowa „logika”.

68. (...) Nierzadko uważa się, że życie człowieka jeszcze nie narodzonego lub głęboko upośledzonego jest dobrem tylko względnym: w myśl logiki proporcjonalistycznej lub z czystego wyrachowania należałoby je porównać $\mathrm{z}$ innymi dobrami i ocenić $\mathrm{w}$ odniesieniu do nich. Utrzymuje się także, że tylko człowiek znajdujący się w konkretnej sytuacji i osobiście w nią zaangażowany może dokonać poprawnej oceny dóbr, z jakimi ma do czynienia: w konsekwencji, tylko on sam mógłby orzekać o moralności swojej decyzji. Państwo zatem, mając na uwadze zgodne współżycie i harmonię społeczną powinno by uszanować tę decyzję posuwając się nawet do dopuszczenia przerywania ciąży i eutanazji. (...)

Papież odnosi się tu do proporcjonalizmu - poglądu, że działania ludzkie są tym lepsze, im proporcjonalnie $\mathrm{w}$ określonej perspektywie czasowej przynoszą więcej korzyści (i to bez względu na ich podstawową wartość moralną). Użyte tu przez Jana Pawła II pojęcie „logika proporcjonalistyczna" jest - zdaje się - określeniem po raz pierwszy użytym (a co za tym idzie - również wprowadzonym) przez Niego. $Z$ drugiej strony - deprecjonuje proporcjonalizm jako postawę/pogląd o chybionej logice. 
74. Wprowadzenie niesprawiedliwych ustaw prawnych stawia często ludzi moralnie prawych przed trudnymi problemami sumienia dotyczącymi kwestii współpracy, a wynikającymi z obowiązku obrony własnego prawa do odmowy uczestnictwa w działaniach moralnie złych. Decyzje, które trzeba wówczas podjąć, są nieraz bolesne i mogą wymagać rezygnacji z osiągniętej pozycji zawodowej albo wyrzeczenia się słusznych oczekiwań związanych z przyszłą karierą. W innych przypadkach może się zdarzyć, że wykonywanie pewnych działań, ze swej natury obojętnych albo wręcz pozytywnych, przewidzianych przez ustawy prawne globalnie niesprawiedliwe, pozwala na ratowanie zagrożonego życia ludzkiego. $\mathrm{Z}$ drugiej jednak strony można się słusznie obawiać, że gotowość do wykonywania tych działań nie tylko wywoła zgorszenie i przyczyni się do osłabienia niezbędnego sprzeciwu wobec zamachów na życie, ale doprowadzi niepostrzeżenie do coraz powszechniejszego ulegania permisywnej logice.

Aby wyjaśnić tę trudną kwestię moralną, należy przypomnieć ogólne zasady dotyczące wspótudziału $w$ ztych czynach. Stanowczy nakaz sumienia zabrania chrześcijanom, podobnie jak wszystkim ludziom dobrej woli, formalnego współudziału w praktykach, które zostały co prawda dopuszczone przez prawodawstwo państwowe, ale są sprzeczne z Prawem Bożym. Z moralnego punktu widzenia nigdy nie wolno formalnie współdziałać w czynieniu zła. Takie współdziałanie ma miejsce wówczas, gdy dokonany czyn - już to z samej swej natury, już to ze względu na określony kontekst kształtujących go okoliczności - ma charakter bezpośredniego uczestnictwa w działaniu przeciwko niewinnemu życiu ludzkiemu albo też wyraża poparcie dla niemoralnej intencji głównego sprawcy. Takiego współdziałania nie można nigdy usprawiedliwić ani powołując się na zasadę poszanowania wolności drugiego człowieka, ani też wykorzystując fakt, że prawo cywilne je przewiduje i nakazuje: za czyny dokonywane osobiście przez każdego istnieje bowiem odpowiedzialność moralna, od której nikt nie może się uchylić i z której będzie sądzony przez samego Boga (por. $\mathrm{Rz} \mathrm{2,} \mathrm{6;} \mathrm{14,} \mathrm{12).}$

Odmowa współudziału w niesprawiedliwości to nie tylko obowiązek moralny, ale także podstawowe ludzkie prawo. Gdyby tak nie było, człowiek byłby zmuszony popełniać czyny z natury swojej uwłaczające jego godności i w ten sposób jego wolność, której autentyczny sens i cel polega na dążeniu do prawdy i dobra, zostałaby radykalnie naruszona. Chodzi tu zatem o prawo podstawowe, które właśnie z tego względu powinno być przewidziane w ustawodawstwie państwowym i przez nie chronione. Oznacza to, że lekarze, personel medyczny i pielęgniarski oraz osoby kierujące instytucjami służby zdrowia, klinik i ośrodków leczniczych powinny mieć zapewnioną możliwość odmowy uczestnictwa w planowaniu, przygotowywaniu i dokonywaniu czynów wymierzonych przeciw życiu. Kto powołuje się na sprzeciw 
sumienia, nie może być narażony nie tylko na sankcje karne, ale także na żadne inne ujemne konsekwencje prawne, dyscyplinarne, materialne czy zawodowe.

Tak jak poprzednio Papież deprecjonował logikę proporcjonalistyczną, tak teraz czyni tak względem logiki permisywnej. Permisywizm to tolerancja wobec łamania uniwersalnych norm moralnych przy równoczesnym uznawaniu ich. Uznawanie to jest jedynie abstrakcyjne, gdyż normy uznawane nie stanowią pryzmatu, poprzez który ocenia się rzeczywistość i dokonuje osądu siebie i innych osób.

Papież nie uznaje więc logik, które nie są wewnętrznie spójne.

IV CZĘŚĆ, w której omówimy 2 wystąpienia słowa „logika”.

Powyżej omówiliśmy 2 logiki: proporcjonalistyczną i permisywną, a więc takie, które odpowiadają na pytanie ,jakie?” Były one „złe”. Teraz też omówimy 2 logiki, jednak będą one odpowiadały na pytanie „czego?” (odpowiednio: kultu duchowego przyjemnego Bogu i demokratycznego współistnienia) i będą one „dobre”.

86. Logika kultu duchowego przyjemnego Bogu (por. Rz 12, 1) wymaga, aby sławienie Ewangelii życia dokonywało się przede wszystkim w codziennym życiu i wyrażało się przez miłość do innych i dar z samego siebie. W ten sposób całe nasze istnienie będzie się stawać autentycznym i odpowiedzialnym przyjmowaniem daru życia oraz szczerym i wdzięcznym chwaleniem Boga, który ofiarował nam ten dar. To właśnie dokonuje się w tak wielu gestach ofiary, często niepozornej i ukrytej, spełnianej przez mężczyzn i kobiety, dzieci i dorosłych, młodych i starszych, ludzi zdrowych i chorych. (...)

90. (...) Konsekwentny realizm miłości nakazuje służyć Ewangelii życia także poprzez różne formy działalności społecznej i aktywności politycznej, polegające na głoszeniu i obronie wartości życia w naszych coraz bardziej złożonych i pluralistycznych społeczeństwach. Jednostki, rodziny, grupy i stowarzyszenia są odpowiedzialne choć $\mathrm{z}$ różnego tytułu i na różne sposoby - za tę działalność społeczną i za realizację przedsięwzięć w dziedzinie kultury, gospodarki, polityki i prawodawstwa, które kierując się szacunkiem dla wszystkich i logiką demokratycznego współistnienia, przyczyniają się do budowania społeczeństwa opartego na uznaniu i ochronie godności każdej osoby oraz na obronie i promocji życia wszystkich. (...)

Można wyciągnąć stąd wniosek, że - według Papieża - logiki czysto ludzkich systemów są złe, a właściwie ukierunkowanego działania - dobre.

W każdej z dwóch następnych omawianych tu encyklik (Ut unum sint i Ecclesia de Eucharistia) pojęcie „logika” pojawia się tylko raz. Jednak 
w obydwu tych przypadkach ma ono charakter dynamiczny (współpraca oznacza działanie, podobnie jak to ma miejsce w przypadku ucztowania

\section{Encyklika Ut unum sint}

43. Coraz częściej zdarza się, że zwierzchnicy Wspólnot chrześcijańskich wypowiadają się razem, w imię Chrystusa, na temat ważnych problemów dotyczących powołania człowieka, wolności, sprawiedliwości, pokoju, przyszłości świata. Tak czyniąc, tworzą komunię opartą na jednym $\mathrm{z}$ najważniejszych elementów chrześcijańskiej misji: element ten to przypominanie społeczeństwu, z należnym realizmem, woli Bożej; przestrzeganie władz i obywateli, by nie wchodzili na drogę, która mogłaby prowadzić do łamania praw człowieka. Jest oczywiste - i dowodzi tego doświadczenie - że w pewnych okolicznościach wspólny głos chrześcijan oddziałuje silniej niż głos odosobniony.

Nie tylko jednak zwierzchnicy Wspólnot jednoczą się w tym dążeniu do jedności. Liczni chrześcijanie wszystkich Wspólnot, powodowani swoją wiarą, uczestniczą razem w śmiałych przedsięwzięciach, które stawiają sobie za cel przemianę świata, tak aby zwyciężył w nim szacunek dla praw i potrzeb wszystkich, zwłaszcza ubogich, poniżonych i bezbronnych. W Encyklice Sollicitudo rei socialis z radością pisałem o tej współpracy, podkreślając, że Kościół katolicki nie może się od niej uchylić. Chrześcijanie bowiem, którzy niegdyś działali niezależnie od siebie, dzisiaj wspólnie służą tej sprawie, aby dobroć Boża mogła zatryumfować.

Logika tej współpracy wypływa z samej Ewangelii. Dlatego powiedziałem, przypominając to, co już napisałem w mojej pierwszej Encyklice Redemptor hominis, „że nigdy nie przestanę tego podkreślać i będę popierał każdy wysiłek podejmowany w tym kierunku na wszystkich płaszczyznach, w których spotykamy naszych braci chrześcijan” i dziękowałem również Bogu „za to, czego dokonał On w innych Kościołach i Wspólnotach kościelnych i za ich pośrednictwem”, a także za pośrednictwem Kościoła katolickiego. Dzisiaj stwierdzam z zadowoleniem, że i tak już rozległa sieć ekumenicznej współpracy nadal nieustannie się rozszerza. Prowadzona jest ogromna praca w tej dziedzinie, między innymi dzięki wysiłkom Ekumenicznej Rady Kościołów.

\section{Encyklika Ecclesia de Eucharistia}

48. Tak jak kobieta z Betanii, Kościót nie obawiał się „marnować”, poświęcając najlepsze swoje zasoby, aby wyrażać pełne adoracji zdumienie wobec niezmierzonego daru Eucharystii. Nie mniej niż pierwsi uczniowie, którzy mieli przygotować „dużą salę”, Kościół w ciągu wieków i przy zmieniających się kulturach czuł się zobowiązany, aby sprawować Eucharystię w oprawie godnej tej wielkiej ta- 
jemnicy. Nawiązując do słów i gestów Jezusa, i rozwijając obrzędowe dziedzictwo judaizmu, narodziła się liturgia chrześcijańska. Cóż może wystarczyć, aby w odpowiedni sposób przyjąć dar, który Boski Oblubieniec nieustannie czyni z siebie dla Kościoła-Oblubienicy, zostawiając kolejnym pokoleniom wierzących Ofiarę dokonaną raz na zawsze na Krzyżu i czyniąc z siebie samego pokarm dla wszystkich wiernych? Nawet jeżeli logika „uczty” budzi rodzinny klimat, Kościół nigdy nie uległ pokusie zbanalizowania tej „zażyłości” ze swym Oblubieńcem i nie zapominał, iż to On jest także jego Panem, a „uczta” pozostaje zawsze ucztą ofiarną, naznaczoną krwią przelaną na Golgocie. Uczta eucharystyczna jest prawdziwie uczta „święta”, w której prostota znaków kryje niezmierzoną głębię świętości Boga: O Sacrum convivium, in quo Christus sumitur! Chleb łamany na naszych ołtarzach, ofiarowany nam, jako pielgrzymom wędrującym po drogach świata, jest panis angelorum, chlebem aniołów, do którego nie można się zbliżać bez pokory setnika z Ewangelii: „Panie, nie jestem godzien, abyś wszedł pod dach mój” (Mt 8, 8; $Ł k 7,6)$.

\section{Encyklika Fides et ratio}

„Logika” jest nauką, jak i odwołującym się do niej pojęciem określającym porządek. Nic więc dziwnego, że tak ono, jak i rodzime mu pojęcie „logiczny" najczęściej (bo aż 13 razy) pojawia się w ostatniej z omawianych tu encyklik Jana Pawła II - Fides et ratio (Wiara i rozum). W związku z tym również $\mathrm{w}$ tym przypadku wygodnie będzie prowadzić interesującą nas analizę słów „logika” i „logiczny” po wcześniejszym podzieleniu zawierających je cytatów na kilka części (tu jednak będzie to się wiązało z koniecznością poprzestawiania zawierających je paragrafów).

I CZĘŚĆ, w której omówimy 3 wystąpienia słowa „logiczny”.

4. (...) Zdolność do abstrakcyjnej refleksji właściwa dla umysłu ludzkiego pozwala, aby nadał on - poprzez aktywność filozoficzną - ścisłą formę swojemu myśleniu i w ten sposób wypracował wiedzę systematyczną, odznaczającą się logiczną spójnością twierdzeń i harmonią treści. Dzięki temu procesowi w środowisku różnych kultur i w różnych epokach osiągnięto rezultaty, które doprowadziły do zbudowania prawdziwych systemów myślowych.

(...) mimo różnorodności nurtów myślowych istnieje pewien zasób wiedzy, który można uznać za swego rodzaju duchowe dziedzictwo ludzkości. Mamy tu do czynienia jak gdyby z filozofia niesprecyzowana, dzięki której każdy człowiek ma poczucie, że zna te zasady, choćby tylko w formie ogólnej i nieuświadomionej. Zasady te, właśnie dlatego że w pewnej mierze uznają je wszyscy, powinny stanowić jakby punkt odniesienia dla różnych szkół filozoficznych. (...) 
66. W odniesieniu do intellectus fidei, należy przede wszystkim zauważyć, że Boża Prawda, „ukazana nam w Piśmie Świętym i właściwie tłumaczona przez nauczanie Kościoła”, jest sama w sobie zrozumiała, odznacza się bowiem taką logiczną spójnością, że jawi się jako autentyczna dziedzina wiedzy. Intellectus fidei wyjaśnia tę prawdę nie tylko przez to, że ukazuje struktury logiczne i pojęciowe twierdzeń, z których składa się nauczanie Kościoła, ale także i przede wszystkim przez to, że podkreśla zawartą w nich zbawczą treść, przeznaczoną dla pojedynczego człowieka i dla ludzkości. Cały zbiór tych twierdzeń pozwala wierzącemu poznać historię zbawienia, której ukoronowaniem jest osoba Jezusa Chrystusa i Jego tajemnica paschalna. W tę tajemnicę chrześcijanin włącza się wyrażając przyzwolenie wiary. (...)

Logiczny sposób postępowania (tu: wyrażający się m.in. poprzez „logiczną spójność twierdzeń”) wspólny jest wszystkim ludziom poprzez ich zdolność do abstrakcyjnego myślenia i dzięki temu zawsze był i jest w stanie budować systemy myślowe. Posiadają oni wspólny zasób wiedzy zwany „filozofią niesprecyzowaną”, co oznacza, że wspólnie uznają pewne „zasady, choćby tylko w formie ogólnej i nieuświadomionej." Przy tym proste, dobrze wytłumaczone prawdy, dzięki temu że odznaczają się logiczna spójnością, są same w sobie zrozumiałe i „jawią się jako „autentyczna dziedzina wiedzy".

II CZĘŚĆ, w której omówimy pozostałe 3 wystąpienia słowa „logiczny”.

4. (...) Jeżeli rozum potrafi intuicyjnie uchwycić i sformułować pierwsze i uniwersalne zasady istnienia oraz wyprowadzić z nich poprawne wnioski natury logicznej i deontologicznej, zasługuje na miano prawego rozumu, czyli - jak mawiali starożytni - orthos lógos, recta ratio.

29. Jest nie do pomyślenia, aby poszukiwanie tak głęboko zakorzenione w ludzkiej naturze było całkowicie bezcelowe i pozbawione sensu. Już sama zdolność poszukiwania prawdy i stawiania pytań podsuwa pierwszą odpowiedź. Człowiek nie podejmowałby poszukiwania czegoś, o czym nic by nie wiedział i co uważałby za absolutnie nieosiągalne. Tylko perspektywa uzyskania odpowiedzi może go-nakłonić do postawienia pierwszego kroku. Istotnie, tak właśnie dzieje się zazwyczaj w procesie badań naukowych.

Jeśli naukowiec kierujący się jakąś intuicją zaczyna szukać logicznego i sprawdzalnego wyjaśnienia określonego zjawiska, od samego początku jest przekonany, że znajdzie odpowiedź; stąd też nie zraża się niepowodzeniami. 
Nie uważa owej pierwotnej intuicji za bezużyteczną tylko dlatego, że nie osiągnął swojego celu; słusznie uznaje raczej, że nie udało mu się dotąd znaleźć właściwego rozwiązania. (...)

Tym razem - kontynuując nasze rozważanie odnośnie do znaczenia słowa „logiczny” - Jan Paweł II dowartościowuje logiczne myślenie, które pozwala „wyciągać poprawne wnioski”, a zatem jest właściwym narzędziem $\mathrm{w}$ ręku poszukującego prawdy naukowca.

III CZĘŚĆ, w której omówimy 2 wystąpienia słowa „logika”.

5. (...) Niewątpliwie wielką zasługą współczesnej filozofii jest skupienie uwagi na człowieku. Wychodząc od tego i stając w obliczu wielu pytań, rozum jeszcze mocniej odczuł pragnienie coraz szerszej i coraz głębszej wiedzy. W rezultacie zbudowano złożone systemy myślowe, które zaowocowały rozwojem różnych dziedzin wiedzy, sprzyjając postępowi w kulturze i w dziejach. Antropologia, logika, nauki przyrodnicze, historia, język - w pewien sposób cały obszar wiedzy został objęty tym procesem. (...)

91. Komentując wymienione wyżej nurty myślowe, nie próbowałem przedstawić pełnego obrazu obecnej sytuacji filozofii: trudno zresztą byłoby ująć ją w ramy jakiejś jednolitej wizji. Muszę podkreślić, że w rzeczywistości $\mathrm{w}$ wielu dziedzinach zasoby wiedzy i mądrości znacznie się wzbogaciły. Wystarczy tu wymienić logikę, filozofię języka, epistemologię, filozofię przyrody, antropologię, pogłębioną analizę poznania poprzez uczucia, egzystencjalne ujęcie zagadnienia wolności. (...)

W przytoczonych dwóch fragmentach „logika” występuje jako nauka. W pierwszym tekście ukazana jest jako ta dziedzina, której „zasoby wiedzy i mądrości znacznie się wzbogaciły”. Z kolei w drugim tekście Papież stwierdza, że w wyniku zbudowania filozoficznych „złożonych systemów myślowych" logika - jako dziedzina wiedzy - rozwinęła się, tym samym „sprzyjając postępowi w kulturze i w dziejach”. Poprzez to Jan Paweł II widzi więc logikę jako naukę o dużej doniosłości i znaczeniu.

IV CZĘŚŚ, w której omówimy 2 wystąpienia słowa „logika”.

15. (...) Chrześcijańskie Objawienie to prawdziwy drogowskaz dla człowieka, który podlega zarówno uwarunkowaniom mentalności koncentrującej uwagę na subiektywnych doznaniach, jak i ograniczeniom logiki technokratycznej; jest ostatnią daną przez Boga szansą powrotu do pełni pierwotnego zamysłu miłości, którego początkiem było stworzenie. (...) 
81. (...) Aby dobrze współbrzmieć ze słowem Bożym, filozofia musi przede wszystkim odzyskać wymiar mądrościowy jako poszukiwanie ostatecznego i całościowego sensu życia. (...) Ten wymiar mądrościowy jest dzisiaj tym bardziej nieodzowny, że ogromny wzrost technicznego potencjału ludzkości każe jej na nowo i z całą ostrością uświadomić sobie najwyższe wartości. Jeśli te środki techniczne nie będą podporządkowane jakiemuś celowi, który wychodzi poza logikę czystego utylitaryzmu, rychło mogą ujawnić swój charakter antyludzki, a nawet przekształcić się w potencjalne narzędzia zniszczenia rodzaju ludzkiego. (...)

Według Jana Pawła II, aby człowiek mógł się prawidłowo rozwijać, musi wyjść poza „ograniczenia logiki technokratycznej” i „logiki czystego utylitaryzmu" (czym równocześnie stwierdza, że systemy te stanowią okowy dla człowieka).

V CZĘŚĆ, w której omówimy 2 wystąpienia słowa „logika”.

23. (...) Problemem węzłowym, stanowiącym wyzwanie dla każdej filozofii, jest śmierć Jezusa Chrystusa na krzyżu. Tutaj bowiem wszelka próba sprowadzenia zbawczego planu Ojca do kategorii czysto ludzkiej logiki musi się skończyć niepowodzeniem. „Gdzie jest mędrzec? Gdzie uczony? Gdzie badacz tego, co doczesne? Czyż nie uczynił Bóg głupstwem mądrości świata?” (1 Kor 1, 20) - zapytuje z naciskiem Apostoł. Aby mogło się dokonać to, czego pragnie Bóg, nie wystarcza już sama mądrość ludzkich mędrców, ale konieczne jest zdecydowane otwarcie się na przyjęcie rzeczywistości radykalnie nowej: „Bóg wybrał właśnie to, co głupie w oczach świata, aby zawstydzić mędrców (...); i to, co nie jest szlachetnie urodzone według świata i wzgardzone, i to, co nie jest, wyróżnił Bóg, by to, co jest, unicestwić” (1 Kor 1, 27-28).

46. (...) Nie ma przesady w stwierdzeniu, że rozwój znacznej części nowożytnej myśli filozoficznej dokonywał się przy stopniowym oddalaniu się od chrześcijańskiego Objawienia, sprowadzając ją nawet na pozycje jawnie z nim sprzeczne. (...) W sferze badań przyrodniczych rozpowszechniła się stopniowo mentalność pozytywistyczna, która nie tylko zerwała wszelkie powiązania z chrześcijańską wizją świata, ale - co ważniejsze - zrezygnowała też z wszelkich odniesień do wizji metafizycznej i moralnej. W wyniku tego zaistniało niebezpieczeństwo, że niektórzy ludzie nauki, rezygnując z jakichkolwiek odniesień etycznych, nie stawiają już w centrum swej uwagi osoby ludzkiej i całości jej życia. Co więcej, część z nich, świadoma możliwości otwartych przez rozwój techniki, wydaje się ulegać nie tylko logice rynku, ale także pokusie zdobycia demiurgicznej władzy nad przyrodą, a nawet nad samym bytem ludzkim. (...) 
W tych dwóch fragmentach Papież głosi, że sprowadzenie czegoś do ograniczenia będącej domeną człowieka logiki („czysto ludzkiej logiki” czy „logiki rynku”) jest postępowaniem chybionym.

VI CZĘ̧́́Ć, w której omówimy 2 wystąpienia słowa „logika”.

8o. W Piśmie Świętym znaleźć można cały zespół elementów, dostępnych bezpośrednio lub pośrednio, które pozwalają zbudować wizję człowieka i świata o znacznej wartości filozoficznej. Chrześcijanie stopniowo uświadomili sobie, jakie bogactwo kryje się na tych świętych stronicach. (...) Fundamentem tej «filozofii» zawartej w Biblii jest przekonanie, że życie ludzkie i świat mają sens i zmierzają ku pełni, która urzeczywistnia się w Chrystusie Jezusie. Wcielenie pozostanie zawsze centralną tajemnicą, do której należy się odwoływać, aby zrozumieć zagadkę istnienia człowieka, świata stworzonego i samego Boga. Tajemnica ta stawia najtrudniejsze wyzwania przed filozofią, każe bowiem rozumowi przyswoić sobie logikę zdolną obalić mury, w których on sam mógłby się uwięzić. Tylko tutaj jednak sens istnienia osiąga swój szczyt. Zrozumiała staje się bowiem najgłębsza istota Boga i człowieka: w tajemnicy Wcielonego Słowa zostaje zachowana natura Boska i natura ludzka oraz autonomia każdej z nich, a zarazem ujawnia się relacja miłości, która jednoczy je ze sobą, oraz jedyna w swoim rodzaju więź, która unikając wymieszania natur ujmuje je we wzajemnym odniesieniu.

94. Pierwsze problematyczne zagadnienie dotyczy relacji między znaczeniem a prawdą. Jak każdy inny tekst, także źródła interpretowane przez teologa przenoszą przede wszystkim pewien sens, który należy odkryć i ukazać. Otóż sens ten przybiera tu postać prawdy o Bogu, przez Boga samego ukazanej za pośrednictwem świętego tekstu. Tak więc język ludzki staje się ucieleśnieniem języka Boga, który objawia swoją prawdę «zniżając się» przedziwnie do naszego poziomu, zgodnie z logiką Wcielenia. Jest zatem konieczne, aby teolog interpretujący źródła Objawienia postawił sobie pytanie, jaką głęboką i nieskażoną prawdę pragną mu przekazać teksty, niezależnie od ograniczeń narzuconych im przez język. (...)

W tych - ostatnich już spośród tu omawianych - dwóch fragmentach Jan Paweł II mówi o „logice Wcielenia”. Stwierdza, że (jako odnosząca się do zagadnień transcendentalnych) nie do końca jest ona dostępna dla człowieka. $\mathrm{Z}$ drugiej jednak strony - jest ona niezwykle istotna jako ukazującą człowiekowi świat z innej perspektywy. Jest narzędziem, dzięki któremu człowiek może właściwie zrozumieć świat. Tym samym usuwa ograniczenia podane przy omawianiu poprzednich cytatów. 


\section{Podsumowanie}

Papież, postrzegając logike jako naukę, stwierdza, że powstała ona na podstawie filozoficznych „złożonych systemów myślowych”. Ukazuje ją jako dziedzinę, której „zasoby wiedzy i mądrości znacznie się wzbogaciły”, dzięki czemu sprzyja ona rozwojowi ludzkości (dosłownie: „sprzyja postępowi w kulturze i w dziejach"), a co za tym idzie - jest nauką o dużej doniosłości i znaczeniu.

Posługując się pojęciem „logiczny”, Papież stwierdza, że wszyscy ludzie dostrzegają konieczność logicznego myślenia i budowania własnego obrazu świata na podstawie logicznie spójnych systemów (co możliwe jest ze względu na ich zdolność do abstrakcyjnego myślenia). Logiczne myślenie pozwala „wyciągać poprawne wnioski”, a zatem jest właściwym narzędziem choćby w ręku poszukującego prawdy naukowca. W swych encyklikach Papież trzykrotnie używa pojęcia „logiczny wniosek”, który „wysnuwa się" lub „płynie” (ma więc on charakter dynamiczny, a nadto - przy drugim $\mathrm{z}$ tych sformułowań - jest wręcz oczywisty). Mimo to zbadanie tego, czy coś jest logiczne, czy też nie, często wymaga „głębszej analizy”, szczególnie związanej z odniesieniem do dóbr i wartości wyższego rzędu.

Papież logikę, rozumianą jako pewien ludzki system, zawsze określa jako złą lub nie w pełni dobrą (wypowiada się wtedy o niej jako o „poprawnej, ale niewystarczającej” lub „nie w pełni zaspokajającej potrzeby ludzkie", podczas gdy logika ma właśnie za zadanie dobrze służyć człowiekowi). Jan Paweł II, wiedząc, że logika w czystej formie oznacza wewnętrzną spójność, nie może uznać stricte „ludzkich logik”, jako nie spełniających tego wymogu. Zdaniem Papieża ograniczenie rozumowania do tego typu logiki („czysto ludzkiej logiki” czy „logiki rynku”) jest więc postępowaniem chybionym. Aby człowiek mógł się prawidłowo rozwijać, musi wyjść poza ograniczenia tego typu logiki (jakimi dalej są np. „logika technokratyczna” czy „logika czystego utylitaryzmu”). Nie należy opisywać czy postrzegać świata poprzez logiki ograniczone do wąskich dziedzin działalności człowieka, lecz widzieć i oceniać go w szerszej perspektywie. Logiki tego typu, same bowiem będąc ograniczonymi, ograniczają człowieka, a zdaniem Papieża człowiek jest w stanie właściwie zrozumieć świat ( $w$ tym siebie!) dopiero w perspektywie logiki Wcielenia.

W końcu Papież logikę widzi też jako przemyślaną, racjonalną i nakierowaną na określony cel aktywność (ludzką lub boską). Postrzeganie $\mathrm{w}$ ten sposób logiki ma więc charakter dynamiczny (w sensie potencjalnym - jako zamysł, lub aktualnym). Logika dla Jana Pawła II jest więc drogą do dochodzenia do Prawdy. Stwierdza On przy tym, że tego typu działanie człowieka, jako zgodne z prawdą, samo też powinno być zgodne z logiką jego przekonań. Z kolei, idąc za św. Augustynem, Papież uznaje gradację logiczności (a właściwie - nielogiczności) i stwierdza, że nielogiczna jest przede wszystkim logika „Złego” (Szatana).

Ogół tych rozważań możemy jeszcze krócej podsumować stwierdzeniem, że według Papieża nie powinniśmy ograniczać się do wąskich logik 
Wtodzimierz Lapis: Analiza pojęć „logika” $i$,logiczny” w encyklikach Jana Pawta II

ludzkich, lecz w swym działaniu kierować się aktywnością opartą na spójnych, odpowiednio szerokich systemach logicznych (przy czym w działaniu tym możemy odwoływać się zarówno do coraz szerszych zasobów logiki, jak i do własnej „logicznej intuicji”).

\section{Wykorzystane źródła zewnętrzne}

Słownik języka polskiego, t. 2: L-P, PWN, Warszawa 1988, s. 49 - 5 o - definicje opisywanych tu pojęć.

pl.wikipedia.org/wiki/Jan_Pawe\%C5\%82_II - ogólny opis encyklik Jana Pawła II.

www.nauczaniejp2.pl/dokumenty 